\title{
Deletion of class II ARF causes essential tremors through Nav1.6 traffic impairment
}

\author{
Nobutake Hosoi ${ }^{1}$, Koji Shibasaki ${ }^{2}$, Mayu Hosono ${ }^{3}$, Ayumu Konno ${ }^{1}$, Yo Shinoda ${ }^{4}$, Hiroshi \\ Kiyonari $^{5,6}$, Kenichi Inoue ${ }^{6}$, Shinichi Aizawa ${ }^{5}$, Shinichi Muramatsu ${ }^{7}$, Yasuki Ishizaki ${ }^{2}$, \\ Hirokazu Hirai ${ }^{1}$, Teiichi Furuichi ${ }^{8}$, Tetsushi Sadakata ${ }^{3 *}$
}

${ }^{1}$ Department of Neurophysiology and Neural Repair, Gunma University Graduate School of Medicine, Maebashi, Gunma 371-8511, Japan

${ }^{2}$ Department of Molecular and Cellular Neurobiology, Gunma University Graduate School of Medicine, Maebashi, Gunma 371-8511, Japan

${ }^{3}$ Education and Research Support Center, Gunma University Graduate School of Medicine, Maebashi, Gunma 371-8511, Japan

${ }^{4}$ Department of Environmental Health, School of Pharmacy, Tokyo University of Pharmacy and Life Sciences, Hachioji, Tokyo 192-0392, Japan

${ }^{5}$ Genetic Engineering Team, RIKEN Center for Life Science Technologies, Kobe, Hyogo 650-0047, Japan

${ }^{6}$ Animal Resource Development Unit, RIKEN Center for Life Science Technologies, Kobe, Hyogo 650-0047, Japan

${ }^{7}$ Department of Neurology, Jichi Medical University, Shimotsuke, Tochigi 329-0498, Japan.

${ }^{8}$ Department of Applied Biological Science, Tokyo University of Science, Noda, Chiba 278-8510, Japan

*To whom correspondence should be addressed.

E-mail: sadakata-1024@umin.ac.jp

Running title: Class II ARF KO causes essential tremor

Keywords: ARF / axon initial segment / essential tremor / Nav1.6

Number of characters including spaces: 25,839 characters (including spaces) 


\begin{abstract}
ADP-ribosylation factors (ARFs) are a family of small monomeric GTPases consisting of three classes. In the present study, we generated class II ARF-deficient mice $\left(\mathrm{ARF}^{+/-} / \mathrm{ARF}^{-/-}\right)$and found that they exhibited severe movement-associated tremors. Treatment of the mice with propranolol and gabapentin, which alleviate symptoms in patients with essential tremors, similarly reduced the amplitude of the pathologic tremors. In vivo electrophysiological recordings of the $\mathrm{ARF} 4^{+/-} / \mathrm{ARF}^{-/-}$mice revealed that they exhibited reduced excitability of their cerebellar Purkinje cells. Immunohistochemical studies revealed that $\mathrm{ARF}^{+/-} / \mathrm{ARF}^{-1-}$ mice exhibit a severe, selective reduction of Nav1.6 proteins that are important for maintaining repetitive action potential firing in the axon initial segments (AISs) of the Purkinje cells. This decrease in Nav1.6 protein expression and the consequent tremors were alleviated by Purkinje cell-specific expression of ARF5. These results indicate that class II ARF mediates the selective trafficking of Nav1.6 to the AISs in cerebellar Purkinje cells, and suggest that the essential tremors can be ascribed to the reduced intrinsic excitability of Purkinje cells, caused by the selective decrease of Nav1.6 proteins in the AISs.
\end{abstract}




\section{Introduction}

Essential tremor (ET) is the most frequent movement disorder, with a prevalence of approximately $4 \%$ among adults aged 40 years and older (Louis et al, 1995). In contrast to the resting tremor that is observed in Parkinson disease, ET is characterized by postural and kinetic components (Pahwa \& Lyons, 2003). Growing clinical and neuro-imaging evidence has implicated cerebellar dysfunction in the pathogenesis of ET, and emerging postmortem studies have identified structural changes in the cerebellum, particularly in PCs (Benito-Leon et al, 2009; Elble \& Deuschl, 2011; Kuo et al, 2011; Louis et al, 2007). The current major model that shares some features of ET uses the $\mathrm{GABA}_{\mathrm{A}}$ receptor inverse agonist, harmaline, to induce a temporary tremor in animals (Wilms et al, 1999). A major limitation of this model is the development of a rapid tolerance to harmaline and a lack of response to anti-ET medication such as propranolol (Iwata et al, 1993; O'Hearn \& Molliver, 1993). GABA $A_{\mathrm{A}}$ receptor $\alpha 1$ subunit-deficient mice are the only genetic animal tremor models subjected to pharmacologic profiling with anti-ET medications (Kralic et al, 2005). However, detailed mechanistic examinations have not been carried out so far.

ARF proteins belong to the Ras superfamily of small GTPases and regulate protein trafficking through the secretory and endocytic pathways (Donaldson \& Jackson, 2011; Mizuno-Yamasaki et al, 2012). Six ARF proteins have been identified so far, and only five are expressed in humans as ARF2 has been lost (Cockcroft et al, 1994). Based on amino acid sequence homology, the six ARFs are grouped into the following three classes: class I (ARF13), class II (ARF4 and 5), and class III (ARF6). Although class II ARFs have been implicated in Golgi-to-ER retrograde transport and dense-core vesicle synthesis (Sadakata et al, 2010; Volpicelli-Daley et al, 2005a), little is known about their role in vivo.

The aim of the current study was to clarify the role of class II ARFs on normal cerebellar functioning. Both ARF4 and ARF5 are widely expressed in the mouse brain, and ARF4 knockout (KO) mice are embryonic lethal (Jain et al, 2012). To elucidate the functional roles of class II ARFs in vivo, we first generated an ARF4 heterozygous (+/-) mouse line and an ARF5 KO (-l-) mouse line and crossed them to produce a class II ARF-reduced mouse line, $\mathrm{ARF}^{+/-} / \mathrm{ARF}^{-/-}$mice. Using $\mathrm{ARF}^{+/-} / \mathrm{ARF}^{-/-}$mice, we found that class II ARFs play an important role in the selective trafficking of Nav1.6 to the AIS and that class II ARF deficiency causes a severe ET phenotype. 


\section{Results and Discussion}

\section{Class II ARF-deficient mice exhibit severe movement-associated tremors}

ARF4 and ARF5 KO mice were generated as described in the Materials and Methods section (Figure EV1). As previously described (Jain et al, 2012), ARF4-null homozygotes (ARF4 ${ }^{-1}$ ) were embryonically lethal, whereas the heterozygotes $\left(\mathrm{ARF}^{+/}\right)$were viable, therefore $\mathrm{ARF} 4^{+/-}$ were used for subsequent experiments. The ARF5 KO mice generated in this study is the first ARF5 null mice. Wild-type (WT), $\mathrm{ARF5}^{+/-}$, and $\mathrm{ARF5}^{-/-}$pups were born at the expected 1:2:1 Mendelian frequency. Neither ARF4 nor ARF5 proteins were detected in the respective KO mice, and a reduced amount was present in those of heterozygous mice (Figure EV1). There were no apparent significant phenotypic abnormalities in the $\mathrm{ARF}^{+/-}$nor the $\mathrm{ARF}^{-/-}$mice. While $\mathrm{ARF}^{+/-} / \mathrm{ARF}^{-/-}$and WT mice had a similar life expectancy, performance on the Rota-Rod revealed that the double mutants presented motor deficits (Figure 1A). In addition, the $\mathrm{ARF}^{+/-} / \mathrm{ARF}^{-1-}$ mice exhibited severe tremor during movement (but not at rest) after 3-4 weeks of age (Movie EV1).

We quantified tremor by measuring the frequency of head shaking during movement among the four genotypes (WT, $\mathrm{ARF}^{+/-}, \mathrm{ARF}^{-/-}$, and $\mathrm{ARF}^{+/-} / \mathrm{ARF}^{-1-}$ ). Only the $\mathrm{ARF}^{+/-} / \mathrm{ARF}^{-1-}$ mice showed head tremor during movement (Figure 1B). This abnormal behavior resembles the primary symptoms of ET patients and a subset of Parkinson's disease patients, and these two pathologies can be separated pharmacologically. Patients with ET can be treated to reduce their tremors with several drugs, including propanolol and gabapentin (Pahwa \& Lyons, 2003). Both the head shaking frequency and body vibration exhibited by $\mathrm{ARF}^{+/-} / \mathrm{ARF}^{-/-}$mice were decreased by administration of propanolol or gabapentin (Figure 1, C-E). However, L-DOPA/benserazide (effective for improving Parkinson's disease symptoms (Hwang et al, 2005)), sodium valproate (reported to improve cortical myoclonic tremor (Cen et al, 2016)), benserazide alone, or saline treatment had no effect on the tremors (Figure 1, C-E).

Class II ARF-deficient mice exhibit movement-related abnormal brain activity and reduced excitability of cerebellar Purkinje cells

We next examined how the brain activity of $\mathrm{ARF}^{+/-} / \mathrm{ARF}^{-/-}$mice was altered during movement by recording the electroencephalogram (ECoG) and electromyography (EMG) under freely moving conditions (Figure 2, A and B). We did not find any differences in the ECoG between $\mathrm{WT}$ and $\mathrm{ARF}^{+/-} / \mathrm{ARF}^{-/-}$mice during non-moving (resting) periods (Figure 2, A-C). However, ECoG was dramatically changed during movement periods in $\mathrm{ARF} 4^{+/-} / \mathrm{ARF}^{-/-}$mice (Figure 2, A, B and D). Analysis of ECoG power spectrums revealed a significant increase in delta-wave power in moving $\mathrm{ARF}^{+/-} / \mathrm{ARF}^{-/-}$mice as compared to WT mice (Figure 2D). 
Alpha and beta-wave power were also increased during $\mathrm{ARF}^{+/-} / \mathrm{ARF}^{-/-}$mice movement, while the theta-wave power was reduced (Figure 2D). These results indicate that basal brain activities of $\mathrm{ARF}^{+/-} / \mathrm{ARF}^{-/-}$mice were normal (Figure 2C), but that movement triggered abnormal brain activities (Figure 2D). We also analyzed EMG power spectrums in moving WT (Figure 2E) and $\mathrm{ARF}^{+/-} / \mathrm{ARF}^{-/-}$mice (Figure 2F) and found that EMG median power in $\mathrm{ARF}^{+/-} / \mathrm{ARF}^{-/-}$mice was significantly different than that in WT mice (Figure 2, E and F). In our study, the electrodes for ECoG were implanted into the cerebrum, and the reference electrode into the cerebellum (Shibasaki et al, 2015). This recording configuration would mean that the ECoG in our hands reflects differential neuronal activities between the cerebrum and the cerebellum. Therefore, it is possible that the abnormality of ECoG (Figure 2, A-D) arises from the abnormal neuronal activity in the cerebellum.

Interestingly, previous studies have indicated that tremor and motor deficits may be caused by reduced intrinsic excitability of cerebellar PCs (Kalume et al, 2007; Levin et al, 2006). Thus, we recorded APs of PCs in cerebellar slices to examine this possibility in $\mathrm{ARF}^{+/-}{ }^{-\mathrm{ARF}^{-/}}{ }^{-1}$ mice. Injection of depolarizing currents smaller than $600 \mathrm{pA}$ evoked similar $\mathrm{AP}$ firing between $\mathrm{WT}$ and $\mathrm{ARF} 4^{+/-} / \mathrm{ARF}^{-/-}$mice (Figure 3, A and B). However, injection of larger depolarizing currents resulted in much fewer spike discharges in $\mathrm{ARF}^{+/-} / \mathrm{ARF}^{-/-}$mice (Figure $3 \mathrm{~A}$ and $\mathrm{B}$ ). This data indicates that the PC intrinsic excitability is indeed reduced in the case of larger current inputs in $\mathrm{ARF}^{+/-} / \mathrm{ARF}^{-/-}$mice. This phenomena is possibly related to the behavioral phenotype in $\mathrm{ARF} 4^{+-} / \mathrm{ARF}^{-/-}$mice, where tremor-like head shaking occurs only during locomotion, but not at rest as previously descrived. Locomotion increases cerebellar granule cell activity (i.e., excitatory inputs to PCs) and consequently, some PCs increase their simple spike firing rates during movement in vivo (Jelitai et al, 2016). Therefore, PCs are likely to receive fewer spontaneous synaptic current inputs at rest while receiving many more excitatory synaptic current inputs during locomotion. In that context, it is possible that tremors occur in $\mathrm{ARF}^{+/-} / \mathrm{ARF}^{-/-}$mice during movement because their PCs may be unable to properly fire APs in response to movement-driven "increased" synaptic inputs.

We also examined the parameters of AP waveforms in WT and $\mathrm{ARF} 4^{+/-} / \mathrm{ARF}^{-1-} \mathrm{PCs}$. We found no significant differences in most of the parameters, such as maximum rate of rise, maximum rate of fall, AP threshold, AP half width, and afterhyperpolarization (minimum voltage of $\mathrm{AP}$ ), between $\mathrm{WT}$ and $\mathrm{ARF} 4^{+-} / \mathrm{ARF}^{-/-}$mice, except that AP peak was smaller in $\mathrm{ARF}^{+/-} / \mathrm{ARF}^{-/-}$mice (Table 1). The passive electrical properties of PCs, which may affect AP output (Bekkers \& Hausser, 2007), were similar between WT and $\mathrm{ARF} 4^{+/-} / \mathrm{ARF}^{-/-}$mice (Table 1). These results suggest that some active conductance mediated by voltage-dependent sodium or other ion channels, may be altered in $\mathrm{ARF} 4^{+-} / \mathrm{ARF}^{-/-} \mathrm{PCs}$. 


\section{Class II ARF-deficient mice exhibit selective depletion of Nav1.6 proteins in the axon initial segments (AISs) of Purkinje cells}

Cerebellar PCs have two types of pore-forming $\alpha$ subunits $\left(\mathrm{Na}_{\mathrm{v}} 1.1\right.$ and $\left.\mathrm{Na}_{\mathrm{v}} 1.6\right)$ in their voltage-gated sodium channels, which are responsible for AP initiation and propagation (Schaller and Caldwell, 2003). Similar to $\mathrm{ARF}^{+/-} / \mathrm{ARF5}^{-/-}$mice, Nav1.6-deficient mice exhibit ataxia, tremor, complete hind limb paralysis, and reduced action potential (AP) firing in PCs (Levin et al, 2006; Meisler \& Kearney, 2005). We therefore performed immunohistochemical analysis of Nav1.6 expression in $\mathrm{ARF}^{+/-} / \mathrm{ARF}^{-/-}$mice. Nav1.6 expression in the AIS was severely decreased in $\mathrm{ARF}^{+/-} / \mathrm{ARF}^{-/-} \mathrm{PCs}$ (Figure 4, A-G). However, there was no significant difference in the density of Nav1.6 puncta in the dendrites or the soma (Figure EV2) of PCs between WT and $\mathrm{ARF} 4^{+-} / \mathrm{ARF}^{-1-}$ mice. Moreover, no differences were observed between WT and $\mathrm{ARF} 4^{+-} / \mathrm{ARF}^{-/-}$Nav1.6 puncta in the white matter of their cerebella (Figure EV3). These results suggests that class II ARF mediates specifically, the trafficking of Nav1.6 to the AISs of cerebellar PCs.

Ankyrin-G (also known as ankyrin-3) binds to the cytoplasmic loop II-III of sodium channels to recruit and localize the channels to the AIS and the nodes of Ranvier (Dzhashiashvili et al, 2007). Surprisingly, when we examined ankyrin-G localization by immunohistochemistry, we found that ankyrin-G proteins were localized normally in the AISs of $\mathrm{ARF}^{+/-} / \mathrm{ARF}^{-/-}$PCs (Figure 4, H-J).

We next examined the localization of other Nav subtypes in the axons of PCs using an anti-pan-Nav1 antibody. As compared to WT, similar immunoreactivities were identified at the AIS of PCs (Figure EV4). These results suggest that other Nav subtypes may compensate for the reduction of Nav1.6 at AISs in $\mathrm{ARF}^{+/-} \mathrm{ARF}^{-/-} \mathrm{PCs}$.

The $\mathrm{K}_{\mathrm{v}} 3$ family of potassium channels is suggested to maintain high-frequency spiking in cerebellar PCs (Joho \& Hurlock, 2009). In particular, Kv3.3; is suggested to be the dominant subtype expressed in the somas of adult cerebellar PCs (Chang et al, 2007; Joho \& Hurlock, 2009; McKay \& Turner, 2005; Southan \& Robertson, 2000). Immunohistochemical analysis revealed normal expression pattern of the Kv3.3 proteins in $\mathrm{ARF} 4^{+/-} / \mathrm{ARF}^{-/-} \mathrm{PCs}$ (Figure EV5). Collectively, these immunohistochemical results indicate that impaired accumulation of Nav1.6 in AISs may underlie the reduced PC excitability in $\mathrm{ARF} 4^{+/-} / \mathrm{ARF}^{-/-}$mice.

Because cerebellar PCs of Nav1.6-null mutant mice express Nav1.1 at their AISs and nodes of Ranvier in compensation for loss of the Nav1.6 subunit (Van Wart \& Matthews, 2006), class II ARF-null PCs also might express compensatory Nav1.1 subunits at their AISs. If this is the case, because Nav1.1 and Nav1.6 have similar activation gating parameters (Patel et al, 2015), no differences are expected between $\mathrm{WT}$ and $\mathrm{ARF} 4^{+-} / \mathrm{ARF}^{-1-}$ PCs regarding the AP threshold and maximum rate of rise. Our results are in line with this assumption (Table 1). The 
compensatory expression of Nav1.2 is unlikely, because PCs lack Nav1.2 (Kalume et al, 2007; Lorincz \& Nusser, 2008) and Nav1.2 has a much higher activation threshold than Nav1.6 or Nav1.1 (Rush et al, 2005). If Nav1.2 subunits were expressed at the AIS of ARF4 ${ }^{+/} / \mathrm{ARF}^{-/-}$ $\mathrm{PCs}$, AP threshold in $\mathrm{ARF}^{+/-} / \mathrm{ARF}^{-1-}$ mice would have differed from that of WT mice, which was not observed in the present study. In addition, no differences in Kv3.3 (the dominant Kv3-type channels in PCs) immunoreactivity were observed between $\mathrm{WT}$ and $\mathrm{ARF} 4^{+/-} / \mathrm{ARF}^{-1-}$ PCs (Figure EV5). The AP repolarization phase (i.e., AP fall) and AP afterhyperpolarization are mediated by $\mathrm{Kv}$ channels (Joho \& Hurlock, 2009). We found no differences in AP fall and afterhyperpolarization in our study (Table 1), indicating that the Kv channels involved in AP generation are unaffected in the $\mathrm{PCs}$ of $\mathrm{ARF}^{+/-} / \mathrm{ARF}^{-1-}$ mice.

\section{Decrease in Nav1.6 protein expression and the consequent tremors alleviated by Purkinje cell-specific expression of ARF5}

To examine whether the morphological and behavioral defects of $\mathrm{ARF}^{+/-} / \mathrm{ARF}^{-/-}$mice were actually caused by the loss of class II ARF protein in cerebellar PCs, we expressed ARF5 proteins specifically in PCs of $\mathrm{ARF} 4^{+/-} / \mathrm{ARF}^{-/-}$mice using adeno-associated virus serotype- 9 (AAV9) expression vectors. AAV9 expressing ARF5 tagged with HA under the control of PC-specific L7 promoter, was directly administered into the $\mathrm{ARF} 4^{+/-} / \mathrm{ARF}^{-/-}$cerebellum at P14 as described previously (Sawada et al, 2010). The expression of the transgene in the cerebellum was examined 6 weeks after the injection. Figure 5A and 5B shows representative sagittal sections of the cerebellar vermis from $\mathrm{ARF}^{+-}{ }^{+-} / \mathrm{ARF}^{-1-}$ mice injected with the AAV vectors. ARF5 was diffusely expressed in all lobules of the $\mathrm{ARF} 4^{+-} / \mathrm{ARF}^{-/-}$mouse cerebellar vermis (Figure 5A) and its expression was limited to PCs (Figure 5B). The frequency of head shaking of the AAV-injected mice was significantly decreased as compared with that of the PBS-injected mice (Figure 5C). Concomitantly, the linear density of Nav1.6 expression in the AISs of PCs was increased in the ARF5-restored $\mathrm{ARF}^{++-} / \mathrm{ARF}^{-/-}$mice, as compared with that in the PBS-injected mice (control) (Figure 5D-F). Thus, the abnormal behavioral and immunohistochemical phenotypes (i.e., tremor and Nav1.6 mislocalization) were partly rescued by PC-specific class II ARF protein expression. Therefore, we conclude that class II ARF deficiency in cerebellar PCs can contribute to ET directly through impaired localization of Nav1.6 to their AISs.

\section{Function of class II ARFs}

Little is known about the role of the class II ARFs in membrane trafficking. It has been documented that class II ARFs are involved in Dengue virus secretion (Kudelko et al, 2012) and hepatitis C virus replication (Farhat et al, 2016), although the specific mechanisms are unclear. 
In this study, we identified for the first time that class II ARF regulates selective Nav1.6 protein trafficking to the AIS (Figure 4). The AIS has two important physiological functions. One is to initiate APs, and another is to form an axonal barrier (Yoshimura \& Rasband, 2014). In our analysis, class II ARF was not involved in the formation of the AIS (Figure 4), suggesting that $\mathrm{ARF}^{+/-}$/ARF5 $^{-1-}$ PCs have normal axonal barrier functions to prevent nonspecific transport from the soma to axon. Moreover, our results suggest that the class II ARF is not involved in targeting of Nav1.6 to the somatodendritic compartment nor to the nodes of Ranvier (Figures EV2 and EV3). Notably, our data clearly indicates that class II ARFs specifically regulate Nav1.6 targeting to the AIS. Therefore, class II ARFs may play a role as 'ion channel organizers' at the AIS. It was previously suggested that AIS-localized Nav protein is first inserted in the somatodendritic compartments and subsequently endocytosed and restricted to the AIS (Fache et al, 2004). On the other hand, ARF4 and ARF5 double knockdown displayed impaired endosome recycling into the plasma membranes in vitro (Volpicelli-Daley et al, 2005b). Taken together, these results suggest that class II ARFs mediate the fusion of endosomes containing Nav1.6 proteins to the AIS membrane of cerebellar Purkinje cells, although the underlying mechanism remains to be studied in a greater detail.

\section{Essential tremor and cerebellar Purkinje cells}

Kralic et al. (2005) reported a similar ET-like whole body tremor in $\mathrm{GABA}_{\mathrm{A}}$ receptor $\alpha 1$ (Gabral) subunit-deficient mice, which displayed a loss of inhibitory responses in cerebellar PCs. A decisive cause and a critical brain area (or cell type) involved in the etiology of ET were not defined in Gabral KO mice probably because a global KO was used without a genetic rescue experiment (Kralic et al, 2005). Since Gabral KO mice exhibited no abnormalities in the density, gross morphology, or spike firing of the PCs, their ET-like tremor might result from the impairment of GABAergic inhibition somewhere in the motor pathway and not in cerebellar PCs (Kralic et al, 2005). On the other hand, making use of the AAV-mediated PC-specific gene-rescue experiment, we could demonstrate the contribution of cerebellar PCs to the tremor pathology in class II ARF-deficient mice (Figure 5). However, the PC-specific genetic rescue did not fully correct the tremor phenotype in ARF-deficient mice, probably because not enough class II ARF proteins are expressed in the whole cerebellum. Alternatively, a possible abnormality in other regions, including the motor pathway, in addition to cerebellar PCs may be involved in the ET pathology, as proposed by Kralic et al. (2005). The abnormal ECoG observed in class II ARF-deficient mice may reflect the aberrant AP firing of neurons in the cerebral cortex to which we did not deliver the rescue vector virus in the present study.

Finally, it should be noted that the pathologic tremor of our class II ARF-deficient mice showed a remarkable pharmacological similarity with that of human patients with ET. 
Thus, the dysfunction of class II ARFs and the consequent disorganization of the ion channel composition (i.e. loss of Nav1.6) at the AIS may be few of the causes underlying human ET. We propose $\mathrm{ARF} 4^{+/} / \mathrm{AFR}^{-/-}$mice as a suitable animal model to elucidate the mechanisms of ET in humans, which may contribute to the development of future interventions. 


\section{Materials and Methods}

\section{Animals}

All procedures for the care and treatment of animals were carried out according to the Japanese Act on the Welfare and Management of Animals and the Guidelines for the Proper Conduct of Animal Experiments issued by the Science Council of Japan. All experimental protocols were reviewed and approved by the Gunma University Animal Care and Experimentation Committee and by the Institutional Animal Care and Use Committee of the RIKEN Kobe Branch.

\section{Generation of ARF4 and ARF5 knockout mice and genotyping}

ARF4 and ARF5 knockout (KO) mice (Accession No. CDB0884K (ARF4) and CDB0885K (ARF5); http://www2.clst.riken.jp/arg/mutant\%20mice\%20list.html) were generated as described (http://www2.clst.riken.jp/arg/methods.html). The targeting vector contained two loxP sites and a neomycin resistance cassette for selection in embryonic stem (ES) cells derived from C57BL/6 mice (Kiyonari et al, 2010). For gene targeting, ES cell screening and chimera production were performed. The chimeric mice were mated with C57BL/6 mice to generate F1 heterozygotes, which were then crossed with CAG-Cre mice (Sakai \& Miyazaki, 1997), to produce ARF4 and ARF5 KO offspring (Figure EV1). Genomic DNA was isolated from mouse ear punched tissues and yolk sac for genotyping. ARF4 KO mouse alleles were genotyped by allele-specific PCR with the following primers: ARF4 (forward primer) 5'-ctatgcagatggtgttaggc-3', ARF4 (WT primer) 5'-gccctccacatcaacacttc-3', and ARF4 (KO primer) 5'-caatgctaggacaatgaggc-3'. The ARF4 (forward) and ARF4 (WT) primer set yields a product of $140 \mathrm{bp}$, while the ARF4 (forward) and ARF4 (KO) primer set yields a product of 556 bp. ARF5 KO mouse alleles were genotyped using allele-specific PCR with the following primers: ARF5 (forward primer) 5'-acttgagaaatgggtcaccg-3', ARF5 (WT primer) 5'cgatctctgcaaaggacaca-3', and ARF5 (KO primer) 5'- cgagggaaaagctgtgttgt-3'. The primer set ARF5 (forward) and ARF5 (WT) yields a product of 156 bp and primer set ARF5 (forward), ARF5 (KO) yields a product of $280 \mathrm{bp}$. All of the engineered animals studied were backcrossed onto C57BL/6J for $>5$ generations.

\section{Antibodies}

Rabbit polyclonal anti-ARF4 and anti-ARF5 antibodies were raised against mouse ARF4 (ERIQEGAAVLQKMLLEDC) and ARF5 (ERVQESADELQKMLQEDC) peptide-KLH conjugates, respectively. These were then affinity-purified against MBP-tagged full-length ARF4 and ARF5 proteins covalently coupled to CNBr-activated Sepharose 4B, and were subsequently used for Western blotting $(1: 1,000)$. The following primary antibodies were used 
for immunohistochemistry: mouse monoclonal anti-calbindin (1:500; cat. no. 214011, Synaptic Systems, Göttingen, Germany); rabbit polyclonal anti-Nav1.6 (1:400; cat. no. P3088, Sigma-Aldrich, St. Louis, MO); mouse monoclonal pan-Nav1 (1:4; cat. no. 73-405, Antibodies Inc., Davis, CA); mouse monoclonal anti-Kv3.3 (1:300; cat. no. 75-354, Antibodies Inc.); mouse monoclonal anti-ankyrin-G (1:300; cat. no. 75-147, Antibodies Inc.); rabbit anti-ankyrin-G (1:500; cat. no. 386003, Synaptic Systems); and rat monoclonal anti-HA (1:250; cat. no. 1867423; Roche, Mannheim, Germany).

\section{Electroencephalogram (EEG) and electromyogram (EMG) recording and analysis}

EEG electrodes that were connected to a $5 \mathrm{~mm}^{2}$ computer circuit board were implanted into the cortex, and the reference electrode into the cerebellum (Shibasaki et al, 2015). In addition, electrodes for EMG were implanted into the neck muscle. The mice were then housed separately for a recovery period of at least 7 days. After 7 days, the mice were connected to an EEG machine (EEG4214, Nihon Koden, Japan), and cortical EEG (ECoG) and EMG were recorded under freely moving conditions. The ECoG and EMG recordings were taken and matched chronologically with behaviors obtained by infrared cameras. The outputs of the ECoG and EMG were connected to a PowerLab8/30 (AD Instruments, Colorado Springs, CO) to digitally convert the analog data. The digital EEG data were analyzed using the LabChart 8.0 software. The data was categorized into either stationary or moving conditions according to the EMG and behavioral movies. The EMG power spectrums were then calculated using the Labchart8.0 software.

\section{Cerebellar slice electrophysiology}

Parasagittal slices (250-300 $\mu \mathrm{m}$ in thickness) of the cerebellar vermis were prepared from adult mice (7-20 weeks old) as described previously (Mitsumura et al, 2011), except that cutting solution (pH adjusted to 7.4 with $\mathrm{HCl}$ ) contained NMDG (93 mM), $\mathrm{KCl}(2.5 \mathrm{mM}), \mathrm{CaCl}_{2}(0.5$ $\mathrm{mM}), \mathrm{MgCl}_{2}(10 \mathrm{mM}), \mathrm{NaH}_{2} \mathrm{PO}_{4}(1.25 \mathrm{mM}), \mathrm{NaHCO}_{3}(30 \mathrm{mM})$, HEPES $(20 \mathrm{mM})$, and D-glucose $(20 \mathrm{mM})$. The cerebellar slices were incubated at $32{ }^{\circ} \mathrm{C}$ for $20-30 \mathrm{~min}$ in the above solution supplemented with sodium ascorbate $(5 \mathrm{mM})$, thiourea $(2 \mathrm{mM})$, and sodium pyruvate (3 mM) (Zhao et al, 2011), and bubbled with 95\% $\mathrm{O}_{2}$ and $5 \% \mathrm{CO}_{2}$. The slices were then incubated at room temperature for more than 1 hour before recording in artificial cerebrospinal fluid (ASCF, pH 7.4) consisting of $\mathrm{NaCl}(125 \mathrm{mM}), \mathrm{KCl}$ (2.5 mM), $\mathrm{CaCl}_{2}$ (2 mM), $\mathrm{MgCl}_{2}$ (1 $\mathrm{mM}), \mathrm{NaH}_{2} \mathrm{PO}_{4}(1.25 \mathrm{mM}), \mathrm{NaHCO}_{3}(26 \mathrm{mM})$, D-glucose $(10 \mathrm{mM})$, bubbled with $95 \% \mathrm{O}_{2}$ and $5 \% \mathrm{CO}_{2}$, and supplemented with L-ascorbic acid $(0.4 \mathrm{mM})$, myoinositol $(2 \mathrm{mM})$, and sodium pyruvate $(2 \mathrm{mM})$. Whole-cell recordings were performed at room temperature from the somata of Purkinje cells (PCs) using patch pipettes (2-4 M $\Omega$ ) pulled from borosilicate glass (Harvard 
Apparatus, Holliston, MA) or \#0010 glass (World Precision Instruments, Sarasota, FL). The pipette solution ( $\mathrm{pH} 7.3$ ) contained potassium gluconate (135 mM), HEPES (10 mM), KCl (5 $\mathrm{mM}), \mathrm{NaCl}(5 \mathrm{mM}), \mathrm{Mg}$-ATP $(5 \mathrm{mM}), \mathrm{Na}-\mathrm{GTP}(0.5 \mathrm{mM})$, EGTA $(0.1 \mathrm{mM})$, and 0-5 phosphocreatine. During recordings, picrotoxin $(100 \mu \mathrm{M})$ was added to the ACSF extracellular solution to block inhibitory synaptic transmission mediated by $\mathrm{GABA}_{\mathrm{A}}$ receptors. Membrane potential was recorded from the patched PCs in the current-clamp mode of a MultiClamp 700B amplifier (Molecular Devices, Sunnyvale, CA) with its bridge balance and capacitance neutralization circuit. Reported membrane potentials were not corrected for junction potential $(-14.6 \mathrm{mV}$ ). Action potentials (APs) were evoked by injecting depolarizing current steps from 0 to $1000 \mathrm{pA}$ in $50 \mathrm{pA}$ increments every $4-8 \mathrm{~s}$. PC membrane potentials before the current injection were held at $-66 \mathrm{mV}$ in order to minimize voltage-dependent changes in the availability of ion channels. AP occurrences were detected by a level-crossing threshold of -10 $\mathrm{mV}$. All the electrical signals were low-pass filtered at $10 \mathrm{kHz}$ and sampled at $50 \mathrm{kHz}$ with Digidata 1440A and pCLAMP10 software (Molecular Devices). Data analysis was performed using pCLAMP10 and Igor Pro (Wavemetrics, Inc., Lake Oswego, OR) with Neuromatic software (http://www.neuromatic.thinkrandom.com/) and custom-written Igor procedures.

\section{Behavioral tests}

Mice were housed with a 12:12 hr light-dark cycle, with the dark cycle occurring from 20:00 to 8:00. All mice used in the experiments below were littermates from mated heterozygotes unless otherwise noted. The experimenter was blind to the genotype in all behavioral tests.

The head shake monitoring was performed as previously described (Dursun \& Handley, 1993). Mice that were eight to ten weeks old were habituated to the observation cages for $60 \mathrm{~min}$ before video image recording. Test mice received saline, propranolol (10 mg/kg, i.p.), gabapentin (40 mg/kg, i.p.), benserazide (12.5 mg/kg, i.p.), L-DOPA (25 mg/kg, i.p.), and sodium valproate $(300 \mathrm{mg} / \mathrm{kg}$, i.p.). L-DOPA was administrated $20 \mathrm{~min}$ after benserazide injection. Head shakes during movement were counted from video recordings played at $2 \mathrm{x}$ slow motion. The tails of mice were fixed with piano wire, and the vibration of the piano wire was recorded by a 3-axis vibration data logger (cat. no. DT-178A, Sato Shouji Inc., Tokyo, Japan).

Coordination and motor skills of the mice were assessed by an accelerated rotarod test. The Rota-Rod Treadmill (Muromachi Kikai, Tokyo, Japan) consisted of a gridded plastic rod (3 $\mathrm{cm}$ in diameter, $10 \mathrm{~cm}$ long) flanked by two large round plates $(50 \mathrm{~cm}$ in diameter). The rod accelerated from 0 to 40 revolutions per minute for $3 \mathrm{~min}$ and remained at the top speed for 1 additional minute. Each test consisted of 4 trials with a $10 \mathrm{~min}$ rest between each trial, and the time that each mouse spent on the rod was recorded. 


\section{Immunohistochemistry}

C57BL/6J male mice were deeply anesthetized with an overdose of diethyl ether and transcardially perfused with phosphate-buffered saline (PBS) and then with Zamboni's fixative (2\% paraformaldehyde in $0.1 \mathrm{M}$ phosphate buffer, $\mathrm{pH} 7.4$, containing $0.2 \%$ picric acid). Tissues were dissected, post-fixed in Zamboni's fixative at $4{ }^{\circ} \mathrm{C}$ for $5 \mathrm{~h}$, and cryoprotected by immersion in $15 \%$ sucrose in PBS overnight at $4{ }^{\circ} \mathrm{C}$. After embedding in Tissue-Tek OCT compound (Sakura Finetek, Tokyo, Japan), tissues were frozen on dry ice powder, and sectioned at a thickness of $14 \mu \mathrm{m}$ using a cryostat (CM1950, Leica Microsystems, Frankfurt, Germany) held at $-18{ }^{\circ} \mathrm{C}$. The sections were air-dried for $1 \mathrm{~h}$ and rinsed in PBS three times. After blocking with 5\% bovine serum albumin (BSA) and 0.3\% Triton X-100 in PBS at room temperature for $1 \mathrm{~h}$, the sections were incubated at $4^{\circ} \mathrm{C}$ overnight with the primary antibodies in immunoreaction buffer ( $2 \times$ PBS containing $0.3 \%$ Triton X-100 and 1\% BSA). The sections were then washed in PBS, incubated at room temperature for $1 \mathrm{~h}$ with the appropriate secondary antibodies in immunoreaction buffer, and washed again in PBS. Stained sections were mounted in Vectashield mounting medium (Vector Laboratories, Peterborough, England) and observed under a fluorescence microscope (BX51, Olympus, Tokyo, Japan) equipped with a CCD camera (VB-7000, Keyence, Osaka, Japan). Digital images were processed using Adobe Photoshop CS5.1 software (Adobe, San Jose, CA).

\section{Production of AAV Vectors}

To express the ARF5 gene with a C-terminal hemagglutinin (HA) tag in PCs, we constructed the adeno-associated virus (AAV) vector plasmid (pAAV-L7-4-minCMV-ARF5-HA), which was designed to express ARF5 under the control of a truncated L7 promoter with a minimal cytomegalovirus sequence (minCMV) (Sawada et al, 2010). Recombinant AAV serotype 9 (AAV9) particles were generated by the cotransfection of the following three plasmids in HEK293T cells: pAAV-L7-4-minCMV-ARF5-HA, pHelper (Stratagene, La Jolla, CA), and pAAV2/9 (kindly provided by Dr. J. Wilson). The viral particles were purified by ammonium sulfate precipitation and iodixanol continuous gradient centrifugation as described previously (Miyake et al, 2012). The genomic titer of the purified AAV9 viral particles as determined by real-time PCR was $2.32 \times 10^{13}$ vector genomes $/ \mathrm{ml}$.

\section{Statistical analyses}

Statistical analyses were performed using the Excel Statistics (Statcel 3; Social Survey Research Information Co, Ltd, Tokyo, Japan) and GraphPad Prism7 software (Graphpad Software, La Jolla, CA, USA). All data are presented as mean \pm SEM. Differences between groups were analyzed using either unpaired Student's $t$-test, one-way ANOVA followed by Scheffe post hoc 
test, or two-way ANOVA followed by a Holm-Sidak's post hoc test, according to each experimental design. $P<0.05$ was considered statistically significant.

\section{Acknowledgements}

This study was supported by Grants-in-Aid for Scientific Research from Japan Intractable Diseases Research Foundation, Takeda Science Foundation, Sumitomo Foundation, SENSHIN Medical Research Foundation, Novartis Pharma, Life Science Foundation of Japan, Kawano Masanori Memorial Public Interest Incorporated Foundation for Promotion of Pediatrics, MEXT/JSPS KAKENHI Grant Numbers JP25110707, JP25430061, JP15H05934.

\section{Author contributions}

$\mathrm{NH}, \mathrm{KS}$, and TS designed the experiments. NH, KS, MH, AK, YS, HK, KI, SM, and TS performed the experiments. $\mathrm{NH}, \mathrm{KS}$, and TS analyzed the data. $\mathrm{NH}, \mathrm{KS}$, and TS wrote the paper. NH, KS, SA, SM, YI, HH, TF, and TS contributed to the discussion.

\section{Conflict of interest}

The authors have declared that no conflict of interest exists. 


\section{References}

Bekkers JM, Hausser M (2007) Targeted dendrotomy reveals active and passive contributions of the dendritic tree to synaptic integration and neuronal output. Proc Natl Acad Sci US A 104: 11447-11452

Benito-Leon J, Alvarez-Linera J, Hernandez-Tamames JA, Alonso-Navarro H, Jimenez-Jimenez FJ, Louis ED (2009) Brain structural changes in essential tremor: voxel-based morphometry at 3-Tesla. J Neurol Sci 287: 138-142

Cen ZD, Xie F, Xiao JF, Luo W (2016) Rational search for genes in familial cortical myoclonic tremor with epilepsy, clues from recent advances. Seizure 34: 83-89

Chang SY, Zagha E, Kwon ES, Ozaita A, Bobik M, Martone ME, Ellisman MH, Heintz N, Rudy B (2007) Distribution of Kv3.3 potassium channel subunits in distinct neuronal populations of mouse brain. J Comp Neurol 502: 953-972

Cockcroft S, Thomas GM, Fensome A, Geny B, Cunningham E, Gout I, Hiles I, Totty NF, Truong O, Hsuan JJ (1994) Phospholipase D: a downstream effector of ARF in granulocytes. Science 263: 523-526

Donaldson JG, Jackson CL (2011) ARF family G proteins and their regulators: roles in membrane transport, development and disease. Nat Rev Mol Cell Biol 12: 362-375

Dursun SM, Handley SL (1993) The effects of alpha 2-adrenoceptor antagonists on the inhibition of 1-(2,5-dimethoxy-4-iodophenyl)-2-aminopropane (DOI)-induced head shakes by 5-HT1A receptor agonists in the mouse. Br J Pharmacol 109: 1046-1052

Dzhashiashvili Y, Zhang Y, Galinska J, Lam I, Grumet M, Salzer JL (2007) Nodes of Ranvier and axon initial segments are ankyrin G-dependent domains that assemble by distinct mechanisms. J Cell Biol 177: 857-870

Elble R, Deuschl G (2011) Milestones in tremor research. Mov Disord 26: 1096-1105

Fache MP, Moussif A, Fernandes F, Giraud P, Garrido JJ, Dargent B (2004) Endocytotic elimination and domain-selective tethering constitute a potential mechanism of protein 
segregation at the axonal initial segment. J Cell Biol 166: 571-578

Farhat R, Seron K, Ferlin J, Feneant L, Belouzard S, Goueslain L, Jackson CL, Dubuisson J, Rouille Y (2016) Identification of class II ADP-ribosylation factors as cellular factors required for hepatitis C virus replication. Cellular microbiology 18: 1121-1133

Foust A, Popovic M, Zecevic D, McCormick DA (2010) Action potentials initiate in the axon initial segment and propagate through axon collaterals reliably in cerebellar Purkinje neurons. $J$ Neurosci 30: 6891-6902

Hwang DY, Fleming SM, Ardayfio P, Moran-Gates T, Kim H, Tarazi FI, Chesselet MF, Kim KS (2005) 3,4-dihydroxyphenylalanine reverses the motor deficits in Pitx3-deficient aphakia mice: behavioral characterization of a novel genetic model of Parkinson's disease. J Neurosci 25: $2132-2137$

Iwata S, Nomoto M, Fukuda T (1993) Effects of beta-adrenergic blockers on drug-induced tremors. Pharmacol Biochem Behav 44: 611-613

Jain S, Yoon SY, Zhu L, Brodbeck J, Dai J, Walker D, Huang Y (2012) Arf4 determines dentate gyrus-mediated pattern separation by regulating dendritic spine development. PloS one 7: e46340

Jelitai M, Puggioni P, Ishikawa T, Rinaldi A, Duguid I (2016) Dendritic excitation-inhibition balance shapes cerebellar output during motor behaviour. Nature communications 7: 13722

Joho RH, Hurlock EC (2009) The role of Kv3-type potassium channels in cerebellar physiology and behavior. Cerebellum 8: 323-333

Kalume F, Yu FH, Westenbroek RE, Scheuer T, Catterall WA (2007) Reduced sodium current in Purkinje neurons from Nav1.1 mutant mice: implications for ataxia in severe myoclonic epilepsy in infancy. J Neurosci 27: 11065-11074

Kawaguchi SY, Sakaba T (2015) Control of inhibitory synaptic outputs by low excitability of axon terminals revealed by direct recording. Neuron 85: 1273-1288

Kiyonari H, Kaneko M, Abe S, Aizawa S (2010) Three inhibitors of FGF receptor, ERK, and 
GSK3 establishes germline-competent embryonic stem cells of C57BL/6N mouse strain with high efficiency and stability. Genesis 48: 317-327

Kralic JE, Criswell HE, Osterman JL, O'Buckley TK, Wilkie ME, Matthews DB, Hamre K, Breese GR, Homanics GE, Morrow AL (2005) Genetic essential tremor in gamma-aminobutyric acidA receptor alpha1 subunit knockout mice. $J$ Clin Invest 115: 774-779

Kudelko M, Brault JB, Kwok K, Li MY, Pardigon N, Peiris JS, Bruzzone R, Despres P, Nal B, Wang PG (2012) Class II ADP-ribosylation factors are required for efficient secretion of dengue viruses. $J$ Biol Chem 287: 767-777

Kuo SH, Erickson-Davis C, Gillman A, Faust PL, Vonsattel JP, Louis ED (2011) Increased number of heterotopic Purkinje cells in essential tremor. J Neurol Neurosurg Psychiatry 82: 1038-1040

Levin SI, Khaliq ZM, Aman TK, Grieco TM, Kearney JA, Raman IM, Meisler MH (2006) Impaired motor function in mice with cell-specific knockout of sodium channel Scn8a (NaV1.6) in cerebellar purkinje neurons and granule cells. $J$ Neurophysiol 96: 785-793

Lorincz A, Nusser Z (2008) Cell-type-dependent molecular composition of the axon initial segment. J Neurosci 28: 14329-14340

Louis ED, Faust PL, Vonsattel JP, Honig LS, Rajput A, Robinson CA, Rajput A, Pahwa R, Lyons KE, Ross GW, Borden S, Moskowitz CB, Lawton A, Hernandez N (2007) Neuropathological changes in essential tremor: 33 cases compared with 21 controls. Brain 130: $3297-3307$

Louis ED, Marder K, Cote L, Pullman S, Ford B, Wilder D, Tang MX, Lantigua R, Gurland B, Mayeux R (1995) Differences in the prevalence of essential tremor among elderly African Americans, whites, and Hispanics in northern Manhattan, NY. Arch Neurol 52: 1201-1205

McKay BE, Turner RW (2005) Physiological and morphological development of the rat cerebellar Purkinje cell. The Journal of physiology 567: 829-850

Meisler MH, Kearney JA (2005) Sodium channel mutations in epilepsy and other 
neurological disorders. J Clin Invest 115: 2010-2017

Mitsumura K, Hosoi N, Furuya N, Hirai H (2011) Disruption of metabotropic glutamate receptor signalling is a major defect at cerebellar parallel fibre-Purkinje cell synapses in staggerer mutant mice. The Journal of physiology 589: 3191-3209

Miyake K, Miyake N, Yamazaki Y, Shimada T, Hirai Y (2012) Serotype-independent method of recombinant adeno-associated virus (AAV) vector production and purification. J Nippon Med Sch 79: 394-402

Mizuno-Yamasaki E, Rivera-Molina F, Novick P (2012) GTPase networks in membrane traffic. Annu Rev Biochem 81: 637-659

O'Hearn E, Molliver ME (1993) Degeneration of Purkinje cells in parasagittal zones of the cerebellar vermis after treatment with ibogaine or harmaline. Neuroscience 55: 303-310

Pahwa R, Lyons KE (2003) Essential tremor: differential diagnosis and current therapy. Am J Med 115: 134-142

Palmer LM, Clark BA, Grundemann J, Roth A, Stuart GJ, Hausser M (2010) Initiation of simple and complex spikes in cerebellar Purkinje cells. The Journal of physiology 588: 1709-1717

Patel RR, Barbosa C, Xiao Y, Cummins TR (2015) Human Nav1.6 Channels Generate Larger Resurgent Currents than Human Nav1.1 Channels, but the Navbeta4 Peptide Does Not Protect Either Isoform from Use-Dependent Reduction. PloS one 10: e0133485

Rush AM, Dib-Hajj SD, Waxman SG (2005) Electrophysiological properties of two axonal sodium channels, Nav1.2 and Nav1.6, expressed in mouse spinal sensory neurones. The Journal of physiology 564: 803-815

Sadakata T, Shinoda Y, Sekine Y, Saruta C, Itakura M, Takahashi M, Furuichi T (2010) Interaction of calcium-dependent activator protein for secretion 1 (CAPS1) with the class II ADP-ribosylation factor small GTPases is required for dense-core vesicle trafficking in the trans-Golgi network. J Biol Chem 285: 38710-38719 
Sakai K, Miyazaki J (1997) A transgenic mouse line that retains Cre recombinase activity in mature oocytes irrespective of the cre transgene transmission. Biochem Biophys Res Commun 237: 318-324

Sawada Y, Kajiwara G, Iizuka A, Takayama K, Shuvaev AN, Koyama C, Hirai H (2010) High transgene expression by lentiviral vectors causes maldevelopment of Purkinje cells in vivo. Cerebellum 9: 291-302

Schaller KL, Caldwell JH (2003) Expression and distribution of voltage-gated sodium channels in the cerebellum. Cerebellum 2: 2-9

Shibasaki K, Sugio S, Takao K, Yamanaka A, Miyakawa T, Tominaga M, Ishizaki Y (2015) TRPV4 activation at the physiological temperature is a critical determinant of neuronal excitability and behavior. Pflugers Arch 467: 2495-2507

Southan AP, Robertson B (2000) Electrophysiological characterization of voltage-gated K(+) currents in cerebellar basket and purkinje cells: Kv1 and Kv3 channel subfamilies are present in basket cell nerve terminals. J Neurosci 20: 114-122

Takayama C, Inoue Y (2003) Normal formation of the postsynaptic elements of GABAergic synapses in the reeler cerebellum. Brain Res Dev Brain Res 145: 197-211

Van Wart A, Matthews G (2006) Impaired firing and cell-specific compensation in neurons lacking nav1.6 sodium channels. J Neurosci 26: 7172-7180

Volpicelli-Daley LA, Li Y, Zhang CJ, Kahn RA (2005a) Isoform-selective effects of the depletion of ADP-ribosylation factors 1-5 on membrane traffic. Mol Biol Cell 16: 4495-4508

Volpicelli-Daley LA, Li Y, Zhang CJ, Kahn RA (2005b) Isoform-selective effects of the depletion of ADP-ribosylation factors 1-5 on membrane traffic. Mol Biol Cell 16: 4495-4508

Wilms H, Sievers J, Deuschl G (1999) Animal models of tremor. Mov Disord 14: 557-571

Yoshimura T, Rasband MN (2014) Axon initial segments: diverse and dynamic neuronal compartments. Curr Opin Neurobiol 27: 96-102 
Zhao S, Ting JT, Atallah HE, Qiu L, Tan J, Gloss B, Augustine GJ, Deisseroth K, Luo M, Graybiel AM, Feng G (2011) Cell type-specific channelrhodopsin-2 transgenic mice for optogenetic dissection of neural circuitry function. Nature methods 8: 745-752 


\section{Figure legends}

Figure 1. Treatment of $\mathrm{ARF}^{+/-} / \mathrm{ARF5}^{-/-}$mice with propranolol and gabapentin reduced the amplitude of the pathologic tremors. (A) Rotarod performance of WT $(n=8)$ and $\mathrm{ARF}^{+/-} / \mathrm{ARF}^{-1-}$ mice $(n=5)$ at 8 weeks of age $(\mathrm{P} 8 \mathrm{w}) . * * P<0.01$, Student's $t$-test. (B) Head tremor frequency of mouse during movement within 3 minutes was counted from video images. WT (white, $n=12$ ), $\mathrm{ARF}^{+/-}$(gray, $n=12$ ), $\mathrm{ARF5}^{-/-}$(gray, $n=12$ ), and $\mathrm{ARF}^{+/-} / \mathrm{ARF5}^{-/-}$mice (black, $n=12$ ) of P7-8w were used. One-way ANOVA and post-hoc Scheffe test were used to determine statistical significance. $* * P<0.01$. Error bars indicate the SEM. (C) Indicated drugs were administrated to the $\mathrm{ARF} 4^{+/-} / \mathrm{ARF}^{-/-}$mice $(n=12)$. $* * P<0.01$ compared to controls by repeated measure ANOVA. Error bars indicate the SEM. (D, E) Vibration before (black) and after (red in D, brown in E) administration of propranolol (D) and gabapentin (E). The tail of mouse was fixed with a piano wire and the vibration of piano wire was recorded by a vibration data logger.

Figure 2. Abnormal ECoG and EMG activities in $\mathrm{ARF}^{+/-} / \mathrm{ARF}^{-/-}$mice upon moving periods. (A, B) Representative ECoG and EMG traces in $\mathrm{WT}$ or $\mathrm{ARF} 4^{+/-} / \mathrm{ARF}^{-1-}$ mouse upon wakefulness. (C, E) ECoG power spectrums were quantified in non-moving, resting mice (Resting) and moving mice (Moving) upon wakefulness. The asterisks indicate statistically significant differences between the genotypes (WT vs. ARF4 ${ }^{+-} / \mathrm{ARF}^{-/-}, n=6$ each, $t$-test). (E, F) A representative EMG power spectrum was calculated in moving WT or $\mathrm{ARF} 4^{+/-} / \mathrm{ARF}^{-/-}$ mouse upon wakefulness.

Figure 3. Reduced intrinsic excitability of cerebellar PCs in class II ARF-deficient mice. (A) Representative traces of AP firing in response to smaller (Left) and larger (Right) depolarizing current injections in WT (gray) and $\mathrm{ARF}^{+/-} / \mathrm{ARF}^{-/-}$(black) PCs. (B) The average number of evoked APs plotted against the injected current amplitudes in WT (white, $n=27$ ) and $\mathrm{ARF}^{+/-} / \mathrm{ARF}^{-/-}$(black, $n=26$ ) PCs. The data were collected from more than 6 mice in each condition. A repeated-measures two-way ANOVA indicates a significant interaction (genotype $x$ injected current; $\left.\mathrm{F}_{22,1122}=2.671 ; P<0.0001\right)$. Multiple comparison tests with Holm-Sidak's method show significant differences between $\mathrm{WT}$ and $\mathrm{ARF} 4^{+-} / \mathrm{ARF}^{-/-}$at injected current strength indicated by $*(P<0.05)$.

Figure 4. Reduced Nav1.6 localization at AIS of PCs in class II ARF-deficient mice. (A-F) Sagittal sections of P8w WT (A-C) and $\mathrm{ARF}^{+/-} / \mathrm{ARF}^{-/-}$(D-F) mouse cerebella were immunolabeled with an anti-Nav1.6 antibody (green) and an anti-calbindin (magenta) antibody. White arrow indicates Nav1.6 immunoreactivities in the AIS of Purkinje cells. Scale bars, 20 
$\mu \mathrm{m}$. (G) The linear density was determined by counting the number of Nav1.6-positive axons of Purkinje cells per millimeter line length throughout the section. WT (white, $n=41$ ), $\mathrm{ARF}^{+-}$ (gray, $n=57$ ), $\mathrm{ARF}^{-/-}$(gray, $n=36$ ), and $\mathrm{ARF}^{+/-} / \mathrm{ARF}^{-1-}$ mice (black, $n=36$ ) at P8w. One-way ANOVA, post-hoc Scheffe test, $* * P<0.01$. (H-I) Sagittal sections of P8w WT (H) and $\mathrm{ARF}^{+/-} / \mathrm{ARF}^{-/-}$(I) mouse cerebella were immunolabeled with an anti-ankyrin-G antibody (green) and an anti-calbindin (magenta) antibody. Scale bars, $20 \mu \mathrm{m}$. (J) The linear densities of ankyrin-G-positive axon of Purkinje cells for WT (white, $n=13$ ), $\mathrm{ARF}^{+/-}$(gray, $n=16$ ), $\mathrm{ARF}^{-/-}$(gray, $n=12$ ), and $\mathrm{ARF} 4^{+-} / \mathrm{ARF}^{-/-}$mice (black, $n=13$ ) at P8w. Error bars indicate SEM.

Figure 5. Rescue of $\mathrm{ARF}^{+/-} / \mathrm{ARF5}^{-/-}$phenotypes by exogenous ARF5 expression. (A, B) Sagittal section of a P8w mouse cerebellum that received injection of AAV9 vectors expressing ARF5-HA at P14 and immunolabeled with an anti-HA antibody (green). Scale bars are $300 \mu \mathrm{m}$ (A) and $20 \mu \mathrm{m}$ (B). (C) Head tremor frequency of P8w mouse during 3 minutes of movement was counted from video recordings. $\mathrm{ARF} 4^{+-} / \mathrm{ARF}^{-1-}$ mice were injected PBS $(n=12)$ or AAV9 vectors expressing ARF5-HA $(n=12)$ at P14. ${ }^{* *} P<0.01$, Student's $t$-test. (D) The linear densities of Nav1.6-positive axons of Purkinje cells for $\mathrm{ARF}^{+/-} / \mathrm{ARF}^{-1-}$ mice injected with PBS $(n=36)$ and AAV9 vectors expressing ARF5-HA $(n=60)$ at P8w. $* * P<0.01$, Student's $t$-test. Error bars indicate the SEM. (E, F) Sagittal sections of P8w ARF4 ${ }^{+-} / \mathrm{ARF}^{-/-}$ mouse cerebella injected with PBS (E) or AAV9 vectors expressing ARF5-HA (F) immunolabeled with an anti-Nav1.6 antibody (green) and an anti-calbindin (magenta) antibodies. White arrow indicates Nav1.6 immunoreactivities in the AIS of PCs. Scale bars, 20 $\mu \mathrm{m}$. 
Table 1. Action potential (AP) parameters and passive electrical properties in WT and $\mathrm{ARF4}^{+/-} / \mathrm{ARF5}^{-/-}$PCs

\begin{tabular}{|l|c|c|c|}
\hline \multicolumn{5}{|c|}{ Action potential (AP) parameters } \\
\hline & $\mathrm{WT}(n=29)$ & $\mathrm{ARF}^{+-} / \mathrm{ARF}^{-/-}(n=26)$ & $t$-test results \\
\hline AP peak $(\mathrm{mV})$ & $31.0 \pm 1.4$ & $26.8 \pm 1.6$ & $p<0.05$ \\
\hline Maximum rate of rise $(\mathrm{mV} / \mathrm{ms})$ & $404.9 \pm 18.2$ & $373.8 \pm 14.0$ & $p=0.181$ \\
\hline Maximum rate of fall $(\mathrm{mV} / \mathrm{ms})$ & $-268.7 \pm 16.1$ & $-248.0 \pm 11.9$ & $p=0.306$ \\
\hline AP threshold $(\mathrm{mV})$ & $-43.2 \pm 1.0$ & $-45.2 \pm 1.1$ & $p=0.205$ \\
\hline AP half amplitude width $(\mathrm{ms})$ & $0.36 \pm 0.02$ & $0.36 \pm 0.01$ & $p=0.900$ \\
\hline AP afterhyperpolarization $(\mathrm{mV})$ & $-58.0 \pm 1.0$ & $-59.2 \pm 1.1$ & $p=0.422$ \\
\hline $\begin{array}{l}\text { Resting membrane potential }(\mathrm{mV}) \\
\text { before current steps }\end{array}$ & $-66.3 \pm 0.45$ & $-67.0 \pm 0.48$ & $p=0.288$ \\
\hline \hline & & & $t$-test results \\
\hline \multicolumn{7}{|c|}{ Passive electrical properties } & $p=0.545$ \\
\hline Membrane capacitance $(\mathrm{pF})$ & WT $(n=38)$ & $\mathrm{ARF}^{+/-} / \mathrm{ARF}^{-/-}(n=30)$ & $p=0.504$ \\
\hline Input resistance $(\mathrm{M} \Omega)$ & $552.1 \pm 45.6$ & $512.3 \pm 46.8$ & $272.3 \pm 36.7$ \\
\hline
\end{tabular}

The first APs evoked by the smallest injected currents were analyzed to estimate AP waveform parameters above. Maximum rates of rise and fall in each AP were measured by detecting positive and negative peak values of its differentiated waveform $(\mathrm{dV} / \mathrm{dt})$, respectively. The AP threshold was defined as the membrane potential at which $\mathrm{dV} / \mathrm{dt}$ exceeded $20 \mathrm{mV} / \mathrm{ms}$. AP half amplitude width was defined as the width at the midpoint between the threshold and the peak of its AP. The passive electrical properties of PCs were estimated using averaged traces of around 20 current responses evoked by hyperpolarizing voltage pulses (from -70 to $-75 \mathrm{mV}, 500 \mathrm{~ms}$ duration) in a voltage clamp mode. 


\section{Expanded View Figure legends}

Figure S1. Generation of ARF4 ${ }^{-/}$and $\mathrm{ARF5}^{-/}$mice. (A) Maps of the murine ARF4 gene, both the targeted allele and the ARF4 KO allele are shown. (B) Maps of the murine ARF5 gene, both the targeted allele and the ARF5 KO allele are shown. Exons are shown as white boxes. The loxP and frt sites are depicted as black and white arrowheads, respectively. (C-F) Immunoblot analysis of E13.5 whole body (ARF4) and P8w cerebellum (ARF5) of WT (+/+), heterozygous (+/-), and homozygous (-/-) mice. Protein lysates were immunoblotted with anti-ARF4, anti-ARF5, and anti-actin antibody.

Figure S2. No difference in Nav1.6 somatodendritic localization in $\mathrm{ARF4}^{+/-} / \mathrm{ARF5}^{-/-}$ Purkinje cells. (A-B) Sagittal sections of P8w WT (A) and $\mathrm{ARF}^{+/-} / \mathrm{ARF}^{-/-}$(B) mouse cerebella were immunolabeled with an anti-Nav1.6 antibody (green) and an anti-calbindin (magenta) antibody. Scale bars, $20 \mu \mathrm{m}$. (C-D) Densities of Nav1.6-positive puncta in primary and secondary dendrites (C) and soma (D) of WT (white, dendrite; $n=40$, soma; $n=48$ ) and $\mathrm{ARF}^{+--}$ARF $^{-/-}$Purkinje cells (black, dendrite; $n=40$, soma; $n=61$ ).

Figure S3. No difference in densities of Nav1.6 puncta in white matter. (A-B) Sagittal sections of P8w WT (A) and $\mathrm{ARF} 4^{+-} / \mathrm{ARF}^{-1-}$ (B) cerebellar white matter were immunolabeled with an anti-Nav1.6 antibody (green) and an anti-calbindin (magenta) antibody. Enlarged images are shown in insets. Scale bars, $10 \mu \mathrm{m}$. (C) Densities of Nav1.6-positive puncta in cerebellar white matter of WT (white, $n=34$ ) and $\mathrm{ARF}^{+/-} / \mathrm{ARF}^{-/-}$PCs (black, $n=21$ ).

Figure S4. Immunoreactivities of anti-pan-Nav1 antibody in the AISs of PCs. (A-F) Sagittal sections of P8w WT $(\mathrm{A}-\mathrm{C})$ and $\mathrm{ARF} 4^{+/-} / \mathrm{ARF}^{-/-}(\mathrm{D}-\mathrm{F})$ mouse cerebella were immunolabeled with an anti-pan-Nav1 antibody (green) and an anti-ankyrin-G (magenta) antibody. White arrow indicates pan-Nav1 immunoreactivities in the AISs of PCs. Scale bars, $20 \mu \mathrm{m}$.

Figure S5. Kv3.3 immunoreactivity in $\mathrm{WT}$ and $\mathrm{ARF}^{+/-} / \mathrm{ARF5}^{-/-}$cerebellum. (A, B) Sagittal sections of P8w WT (A) and $\mathrm{ARF} 4^{+/-} / \mathrm{ARF}^{-/-}$(B) mouse cerebella were immunolabeled with an anti-Kv3.3 antibody. Scale bars, $10 \mathrm{~mm}$. 


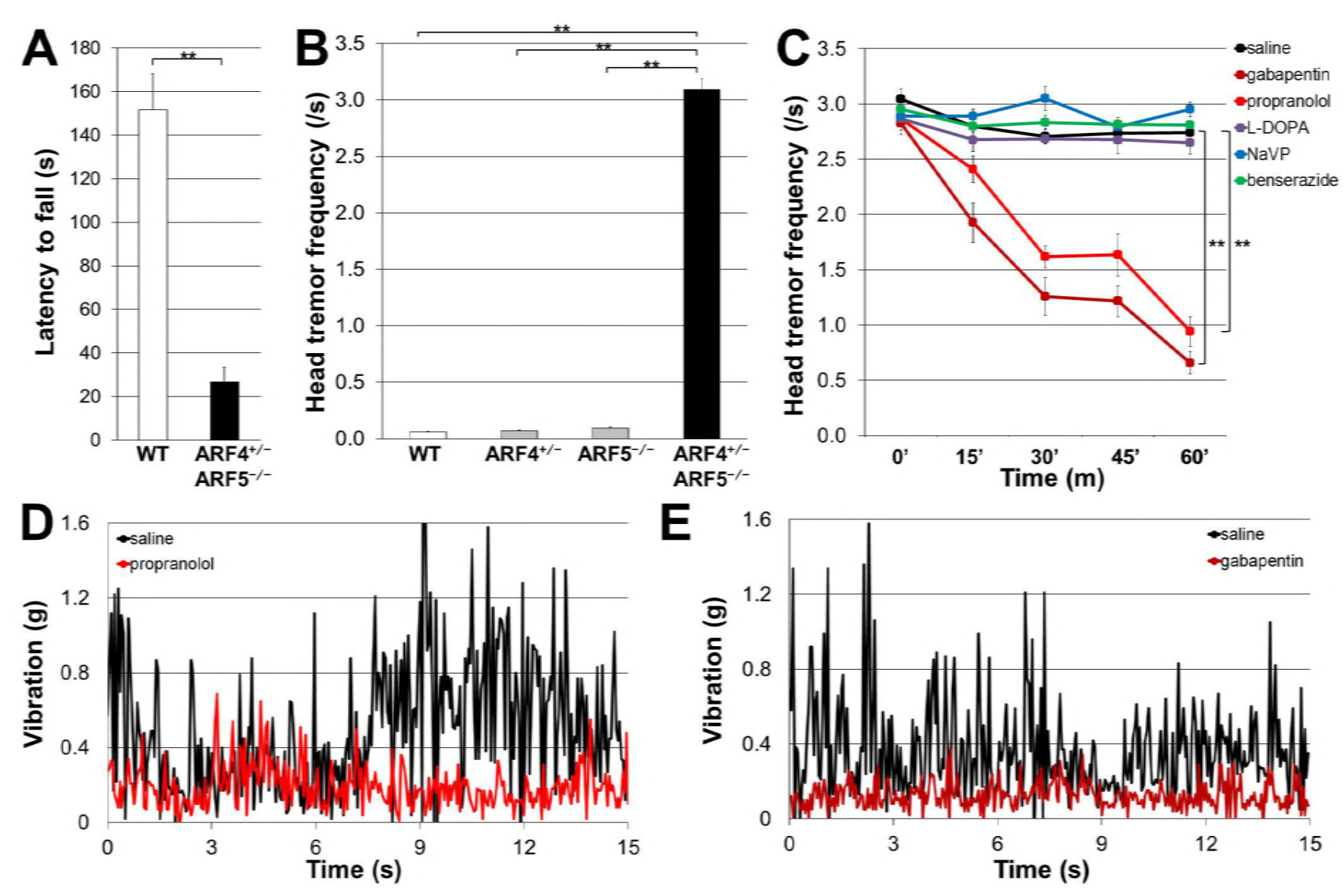


A wT

ECOG

ECh

EMG

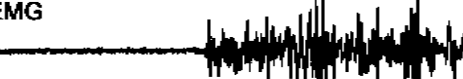

$1+4+2+1+1+4$

Resting

Moving

Resting

C

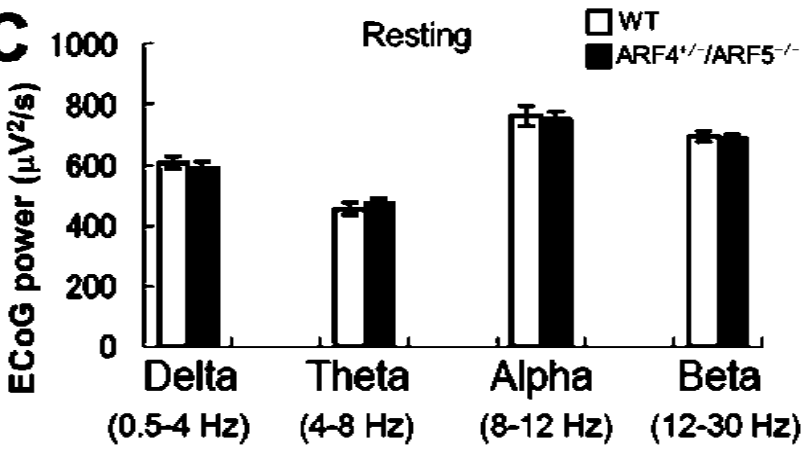

$E$

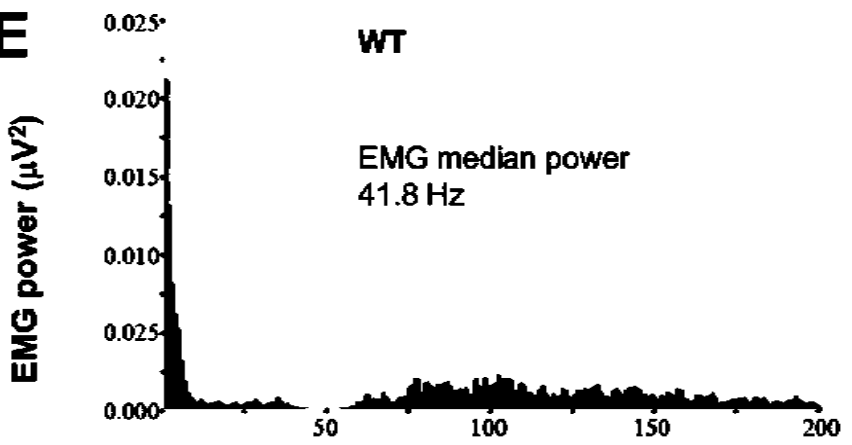

B ARF $^{+/} /$ARF $^{-/}-$

ECOG

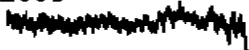

EMG
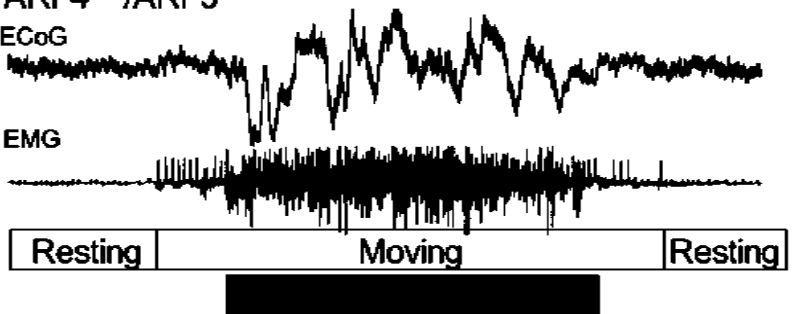

D 5000 Moving

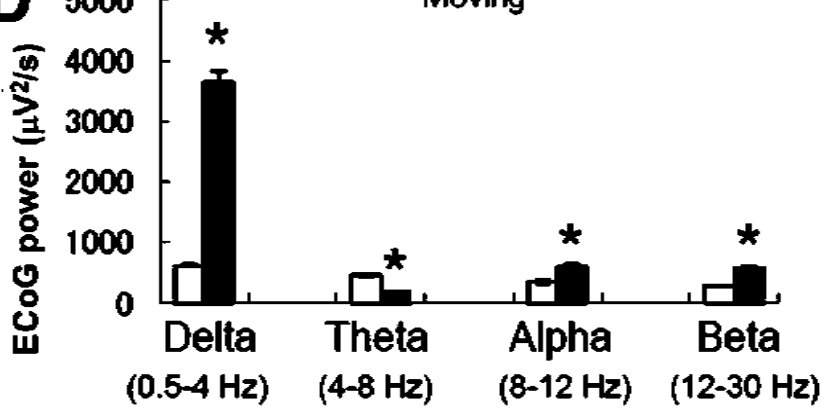

E $\quad 0.025$

ARF4 +'-/ARF5 $^{-1-}$

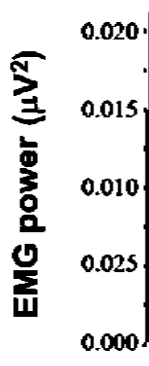

EMG median power

$5.2 \mathrm{~Hz}$ 
A
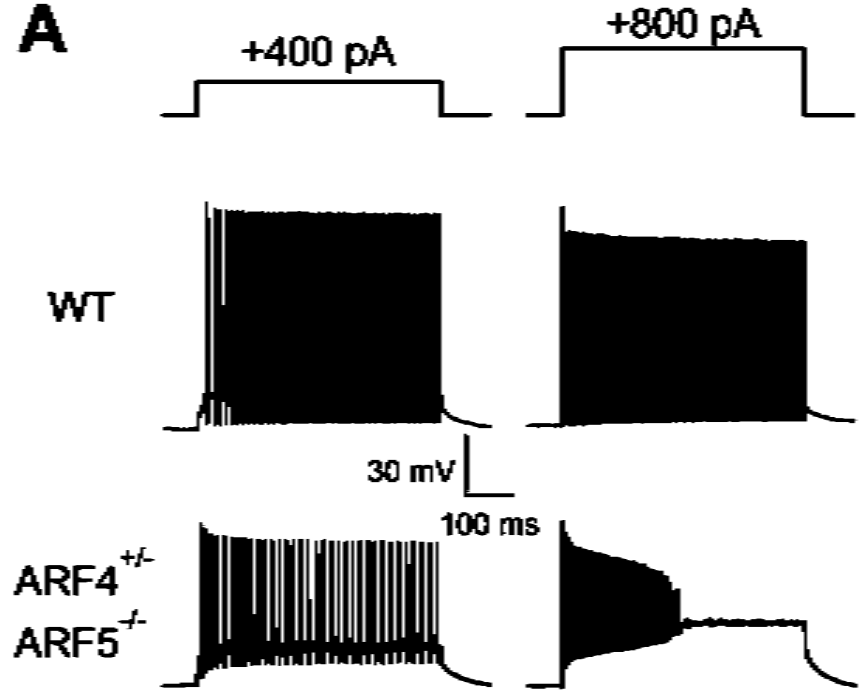

B

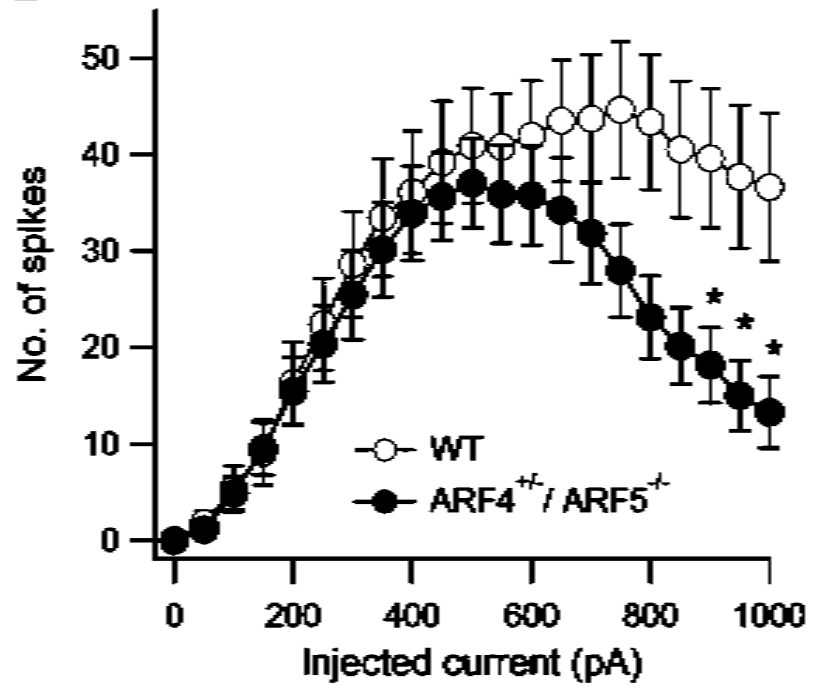




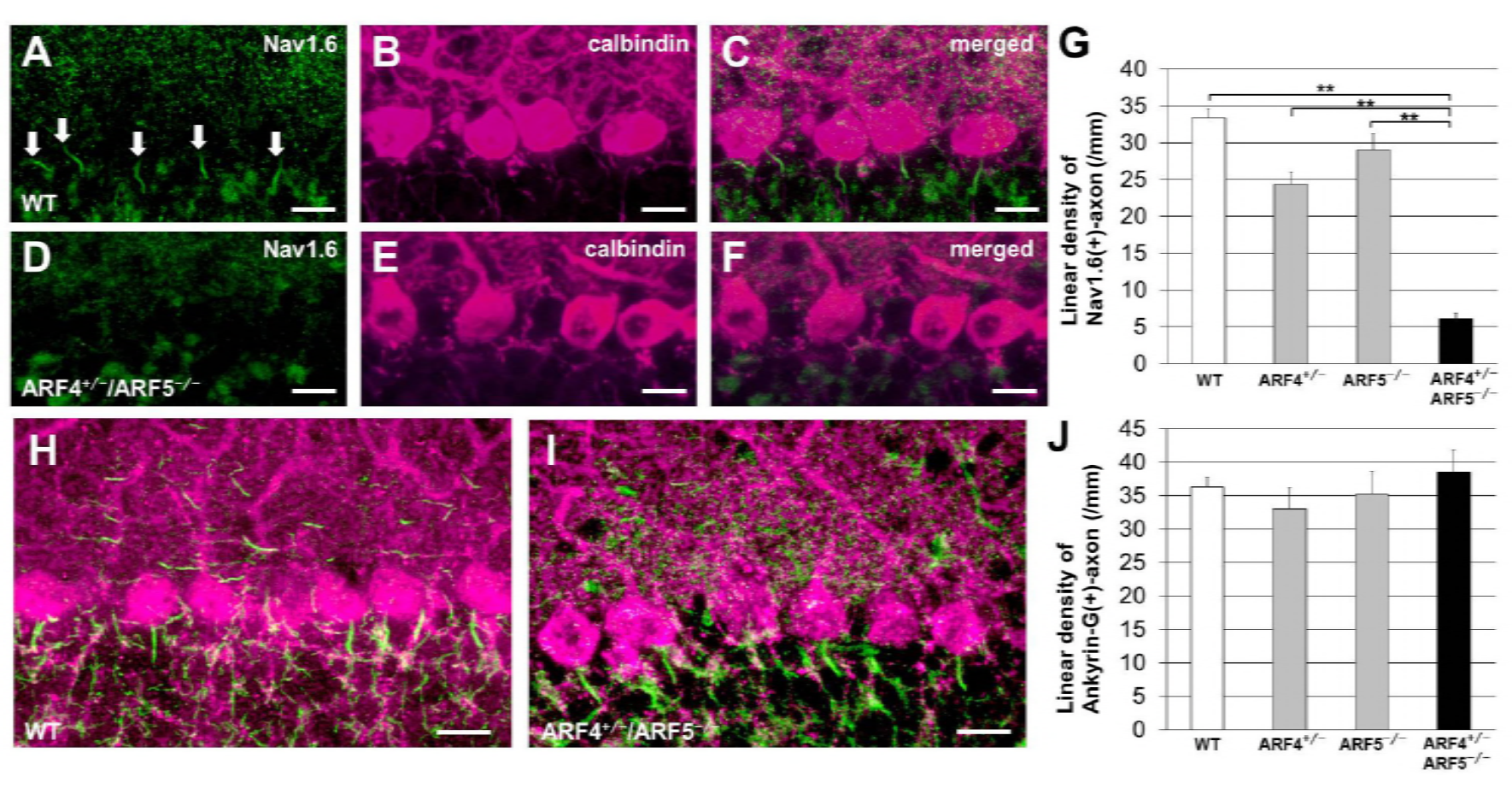


